\title{
IMPROVING STUDENTS' CREATIVE THINKING ABILITY AND LEARNING OUTCOMES THROUGH THE IMPLEMENTATION OF PROBLEM BASED LEARNING MODEL AT ELEMENTARY SCHOOLS
}

\author{
Yunita Cahyarini $^{1}$, Maria Melani Ika Susanti ${ }^{2}$, Maria Indarti Rustamti ${ }^{3}$ \\ 1,2 Universitas Sanata Dharma, Yogyakarta, Indonesia \\ ${ }^{3}$ SD Kanisius Kalasan, Sleman, Indonesia \\ 1yunitacahyarini@gmail.com, ${ }^{2}$ maria.melani.ika@gmail.com, ${ }^{3}$ iin.indarti85@gmail.com
}

\begin{abstract}
This classroom action research aimed to improve creative thinking skills and social studies learning outcomes by implementing problem-based learning model. This research was motivated by the low creative thinking and learning outcomes of the fifth grade elementary school students. Data on creative thinking and learning outcomes in this Classroom Action Research were collected through interviews, observations, and questionnaires. The subjects of this study were 46 students of grade V. This research was carried out in two cycles with the research procedures consisting of planning, implementation, observation, and reflection. The results showed that problem-based learning model improved the students' creative thinking and learning outcomes for social studies material at grade V elementary school. This was showed in the increase of the creative thinking variable with an average initial condition value of 36.83 (creative enough), the first cycle of 43.04 (creative enough) and the second cycle of 45.07 (creative). The variable of students' learning outcomes in the initial data showed an average value of 68.09, the first cycle was 70.33, and the second cycle was 78.59.
\end{abstract}

Keywords: creative thinking, learning outcomes, problem-based learning

\section{PENINGKATAN KEMAMPUAN BERPIKIR KREATIF DAN HASIL BELAJAR SISWA MELALUI PENERAPAN MODEL PEMBELAJARAN BERBASIS MASALAH DI SEKOLAH DASAR}

\begin{abstract}
ABSTRAK
Penelitian tindakan kelas ini bertujuan untuk meningkatkan kemampuan berpikir kreatif dan hasil belajar materi IPS dengan penerapan model pembelajaran berbasis masalah. Penelitian ini dilatarbelakangi rendahnya berpikir kreatif dan hasil belajar siswa kelas V sekolah dasar. Data berpikir kreatif dan hasil belajar dalam Penelitian Tindakan Kelas ini dikumpulkan melalui wawancara, observasi, dan kuesioner. Subjek penelitian ini adalah siswa kelas V sebanyak 46 orang. Penelitian ini dilaksanakan dalam dua siklus dengan prosedur penelitian yang terdiri dari perecanaan, pelaksanaan, observasi, dan refleksi. Hasil penelitian menunjukkan bahwa model pembelajaran berbasis masalah dapat meningkatkan berpikir kreatif dan hasil belajar siswa materi IPS Kelas V sekolah dasar. Hal ini ditunjukkan pada peningkatan variabel berpikir kreatif dengan nilai rata-rata kondisi awal yaitu 36.83 (cukup kreatif), siklus I yaitu 43.04 (cukup kreatif) dan siklus II_yaitu 45.07 (kreatif). Variabel hasil belajar siswa pada data awal menunjukkan nilai rata-rata 68.09, siklus I yaitu 70.33, dan siklus II menjadi 78.59.
\end{abstract}

Kata Kunci: berpikir kreatif, hasil belajar, pembelajaran berbasis masalah

\begin{tabular}{|c|c|c|}
\hline Submitted & Accepted & Published \\
\hline 17 Juni 2021 & 09 Agustus 2021 & 14 September 2021 \\
\hline
\end{tabular}

\begin{tabular}{|l|c|c|}
\hline Citation & $:$ & $\begin{array}{r}\text { Cahyarini, Y., Susanti, M. M. I., \& Rustamti, M. I. (2021). Improving Creative Thinking Ability And Student Learning } \\
\text { Outcomes Through The Application Of Problem Based Learning Models In Elementary School. Jurnal PAJAR } \\
\text { (Pendidikan dan Pengajaran), 5(5), 1260-1266. DOI : http://dx.doi.org/10.33578/pjr.v5i5.8444. }\end{array}$ \\
\hline
\end{tabular}

\section{PENDAHULUAN}

Pendidikan merupakan sebuah kegiatan bimbingan, pembelajaran, pelatihan sehingga seseorang akan berkembang menjadi lebih baik. Pendidikan diberikan kepada seseorang yang sedang belajar. Pendidikan tidak hanya memberikan sebuah materi saja melainkan juga mengembangan potensi yang sudah dimiliki peserta didik. Pendidikan merupakan usaha yang disengaja dan terencana untuk membantu perkembangan anak menuju kedewasaan. 
Undang-undang No. 20 Tahun 2007 tentang Sistem Pendidikan Nasional yang menyatakan bahwa: "Pendidikan adalah usaha sadar dan terencana untuk mewujudkan suasana belajar dan proses pembelajaran agar peserta didik secara aktif mengembangkan potensi dirinya sehingga memiliki kekuasaan spiritual keagamaan, pengendalian diri, kepribadian, kecerdasan, akhlak mulia, serta keterampilan yang diperlukan oleh dirinya, masyarakat, bangsa, dan negara". Oleh karena itu, pendidikan menjadi modal untuk terbentuknya sumber daya manusia yang mampu mengembangkan potensi diri dari proses belajar. Peran guru sangat penting dalam pelaksanaan pendidikan, apabila guru dapat merancang suatu pembelajaran yang menarik dan menyenangkan sehingga diharapkan hasil belajar siswa dapat meningkat.

Perkembangan zaman dan teknologi yang semakin canggih dan modern menuntut sumber daya manusia (SDM) untuk berpikir kreatif, kritis dan mampu memecahkan masalah dalam kehidupan sehari-hari. Sekolah dituntut untuk menciptkan siswa yang mampu berkompetensi di era abad 21 yaitu melalui penguasaan berpikir kreatif maupun kritis sehingga dapat memecahkan masalah secara berkolaborasi dan berkomunikasi. Nahdi (2019) mengungkapkan bahwa setiap orang yang hidup di Abad 21 ini, setidaknya harus memiliki 4 keterampilan yaitu keterampilan berpikir kritis (critical thinking), berpikir kreatif (creative thinking), keterampilan komunikasi (communication), dan keterampilan kolaborasi (collaboration).

Salah satu ketrampilan yang ditekankan dalam penelitian ini adalah kemampuan berpikir kreatif (creative thinking). Kreatif berasal dari bahasa Inggris "create" yang artinya menciptakan, sedangkan kreatif mengandung pengertian memiliki daya cipta, mampu merealisasikan ideide dan perasaannya sehingga tercipta sebuah komposisi dengan warna dan nuansa baru. Orang kreatif lebih fleksibel dibandingkan orang yang kurang kreatif, keflesibelan ini membuat orang kreatif dapat menghindari rintangan-rintangan dalam menghadapi persoalan yang dihadapi (Marliani, 2015). Oleh karena itu berpikir kreatif adalah kemampuan seseorang memunculkan ide yang baru dan inovatif untuk memecahkan suatu permasalahan.

Mata pelajaran IPS adalah salah satu mata pelajaran wajib yang ada di sekolah dasar. Pembelajaran IPS masih sering dianggap susah bagi siswa karena harus mengafalkan banyak kejadian atau peristiwa dan tanggal kejadian. Padahal sebenarnya pembelajaran IPS sangat kental dalam kehidupan sehari-hari, seperti bersosialisasi dengan orang lain dan memahi masalah-masalah yang ada dilingkungan sekitar. Pembelajaran IPS tidak hanya menekankan pada pengetahuan dan menghafalkan saja tetapi juga membina siswa untuk meningkatkan kemampuan berpikir kreatif dalam memecahkan permasalahan dalam kehidupan sehari-hari.

Pandemi covid-19 masuk ke Indonesia pada awal 2020, pemerintah melakukan berbagai cara untuk mencegah penyebaran virus. Salah satu kebijakan pemerintah yang memberikan dampak luas adalah pada bidang pendidikan. Kementerian Pendidikan dan Kebudayaan mengeluarkan surat edaran Nomor 4 Tahun 2020 tentang Pelaksanaan Kebijakan Pendidikan Dalam Masa Darurat Penyebaran covid-19, siswa melaksanakan kegiatan belajar dari rumah yakni melalui pembelajaran daring/jarak jauh. Pembelajaran daring yang dilaksanakan di SD Kanisius Kalasan adalah menggunakan aplikasi zoom dan WhatsApp. Pembelajaran daring ini dilaksanakan setiap pagi hari pukul 07.00-07.45. Peneliti melakukan wawancara kepada wali kelas V SD Kanisius Kalasan pada tanggal 10 November 2020 secara daring menggunakan aplikasi WhatsApp untuk mengetahui bagaimana berpikir kreatif dan hasil belajar mata pelajaran IPS tentang peristiwa sebelum dan sesudah proklamasi kemerdekaan Indonesia.

Peneliti juga melakukan observasi di kelas V pada tanggal 27 Januari 2021 melalui aplikasi zoom. Pembelajaran diawali dengan berdoa, dilanjutkan presensi dengan cara memanggil nama siswa satu persatu tanpa disertai mengisi link presensi di google form, guru memberikan materi dalam bentuk power point maupun word dilanjutkan dengan pemberian tugas. Siswa hanya mendengarkan materi yang dijelaskan guru dan kurang aktif bertanya. Beberapa siswa menjawab 
pertanyaan dari guru, jawaban siswa hanya sesuai dengan materi yang diberikan guru dan bersifat hafalan sedangkan siswa yang lain hanya mengikuti jawaban dari teman yang sudah menjawab. Terlihat bahwa siswa kurang aktif dan kreatif dalam kemampuan berpikirnya. Hal demikian tidak sejalan dengan Nurani, Hartati, \& Sihadi. (2020) kreativitas merupakan kemampuan yang mencerminkan kelancaran, keluwesan, dan orisinalitas dalam berpikir, serta kemampuan untuk berkolaborasi suatu gagasan yang meliputi kemampuan mengembangan, memperkaya, dan memperinci. Berpikir kreatif merupakan kemampuan mengemukakan ide atau pendadapat sehingga menghasilkan pemahaman-pemahaman baru.

Hasil wawancara dan kuesioner menunjukkan bahwa rata-rata capaian berpikir kreatif dan hasil belajar siswa di kelas $\mathrm{V}$ masih tergolong rendah. Data awal nilai rata-rata berpikir kreatif dan hasil belajar berdasarkan hasil kuesioner dan soal evaluasi dapat dilihat pada tabel 1 berikut ini.

Tabel 1. Nilai Rata-rata Kemampuan Berpikir Kreatif dan Hasil Belajar

\begin{tabular}{llcl}
\hline Variabel & Aspek yang Dinilai & Kondisi Awal & Keterangan \\
\hline Berpikir Kreatif & $\begin{array}{l}\text { Rata-rata kemampuan } \\
\text { berpikir kreatif }\end{array}$ & 36.83 & Cukup Kreatif \\
\hline Hasil Belajar & $\begin{array}{l}\text { Rata-rata hasil belajar } \\
\text { siswa }\end{array}$ & 68.09 & Rendah \\
\hline
\end{tabular}

Tabel 1 menunjukkan kondisi awal ratarata nilai berpikir kreatif dan hasil belajar siswa masih belum optimal. Dari hasil wawancara dan kuesioner tersebut perlu upaya perbaikan dalam kegiatan pembelajaran yang lebih baik.

Berkaitan dengan permasalahan yang telah dipaparkan diatas, perlu adanya perbaikan dalam kegiatan pembelajaran secara daring ini. pemilihan model yang tepat diperlukan untuk meningkatkan kemampuan berpikir kreatif dan hasil belajar siswa. Menurut Sapriya (2009) kemampuan berpikir kreatif dapat diterapkan dalam proses pembelajaran dengan tujuan untuk mendorong siswa untuk mengemukakan jawaban sebanyakbanyaknya sesuai dengan fokus masalah yang diajukan atau diberikan oleh guru melalui eksperimen atau penemuan. Peneliti mencoba membuat alternatif pembelajaran yang meningkatkan kemampuan berpikir kreatif siswa dan hasil belajara siswa dengan penggunaan model pembelajaran berbasis masalah sebagai solusi dari permasalahan yang telah dipaparkan tersebut. Lestari, (2020) mengungkapkan bahwa pembelajaran berbasis masalah adalah pembelajaran yang menyediakan masalahmasalah nyata (kontekstual) sebagai sarana untuk mengembangkan keterampilan menyelesaikan masalah bagi peserta didik. Hal lain juga dikemukakan oleh Oktavia (2020) model pembelajaran berbasis masalah adalah model pembelajaran yang dirancang pada proses penyelesaian masalah yang dihadapi secara ilmiah agar siswa mendapat pengetahuan penting.

Peneliti meyakini dan optimis bahwa pembelajaran berbasis masalah dapat menjadi solusi untuk meningkatkan kemampuan berpikir kreatif dan hasil belajar materi IPS di kelas V SD Kanisius Kalasan. Hal ini disebabkan karena karakteristik pembelajaran berbasis masalah dirancang untuk memecahkan masalah-masalah dengan mengembangkan keterampilan dan berpikir kreatif siswa. Penelitian ini bertujuan untuk: 1) meningkatkan kemampuan berpikir kreatif dan hasil belajar siswa kelas V pada mata pelajaran IPS melalui penerapan model pembelajaran berbasis masalah dan 2) mendiskripsikan cara meningkatkan kemampuan berpikir kreatif dan hasil belajar siswa kelas $\mathrm{V}$ pada mata pelajaran IPS melalui penerapan model pembelajaran berbasis masalah.

\section{KAJIAN TEORETIS}

Menurut Silalahi, Girsang, \& Ginting (2020) seluruh aktivitas berpikir dalam kajian 
neurosains menyatakan bahwa kemampuan berpikir diproses secara baik dikedua belahan otak kiri dan kanan karenanya tidak ada anak yang memiliki satu kecenderungan saja, karena otak bekerja secara simultan (serentak) diseluruh bagian dengan hukum silang otak, yang artinya ketika gerak tubuh banyak menggunakan otak kanan berarti otak kirilah yang bekerja dan sebaliknya. Menurut Munandar dalam (Harisudin, 2019) kreativitas atau berpikir kreatif sebagai kemampuan untuk melihat bermacam-macam kemungkinan penyelesaian suatu masalah. Pendapat lain juga disampaikan oleh Nurani, Hartati, \& Sihadi (2020) kreativitas merupakan kemampuan yang mencerminkan kelancaran, keluwesan, dan orisinalitas dalam berpikir, serta kemampuan untuk berkolaborasi suatu gagasan yang meliputi kemampuan mengembangan, memperkaya, dan memperinci. Berpikir kreatif merupakan kemampuan mengemukakan ide atau pendadapat sehingga menghasilkan pemahamanpemahaman baru.

Hasil belajar didapat setelah siswa sudah melakukan proses pembelajaran. Menurut Titik (2020) hasil belajar adalah kemampuan yang dimiliki siswa setelah mereka menerima pengalaman belajar dalam proses pembelajaran. Hasil belajar seorang siswa dibuktikan dengan nilai hasil belajar yang diperoleh setelah proses pembelajaran. Sinar (2018) mengemukakan, hasil belajar adalah hasil seseorang setelah mereka menyelesaikan belajar dari sejumlah mata pelajaran dengan dibuktikan melalui hasil tes yang berbentuk nilai hasil belajar. Pendapat lain juga disampaikan oleh Prayitno (2009) hasil belajar adalah aktivitas yang merupakan wujud dari usaha untuk menguasai bahan yang dipelajari.

Model pembelajaran berbasis masalah (PBM) atau dalam bahasa Inggris disebut problem based learning $(P B L)$ adalah pembelajaran yang menyediakan masalah - masalah nyata (kontekstual) sebagai sarana untuk mengembangkan keterampilan menyelesaikan masalah bagi peserta didik (Lestari, 2020). Pembelajaran berbasis masalah merupakan salah satu model pembelajaran inovatif yang dapat memberikan kondisi belajar aktif kepada siswa. Model pembelajaran berbasis masalah adalah sebuah pendekatan pembelajaran yang menyajikan masalah kontekstual sehingga merangsang peserta didik untuk belajar (Darmadi 2017). Hal lain juga dikemukakan oleh Oktavia (2020) model pembelajaran berbasis masalah adalah model pembelajaran yang dirancang pada proses penyelesaian masalah yang dihadapi secara ilmiah agar siswa mendapat pengetahuan penting. Melalui pembiasaan menyelesaikan masalah - masalah nyata ini diharapkan peserta didik mampu untuk berpikir kritis dan kreatif dalam menyikapi setiap masalah yang dihadapi baik di dalam proses belajar di sekolah maupun kehidupan sehari - hari di dalam masyarakat sehingga secara bertahap peserta didik mampu mengembangkan pengetahuannya.

\section{METODE PENELITIAN}

Jenis Penelitian yang digunakan adalah penelitian tidakan kelas (PTK). Subjek penelitian ini adalah seluruh siswa kelas V SD Kanisius Kalasan Kabupaten Sleman Tahun Ajaran 2020/2021 dengan jumlah siswa sebanyak 46. Penelitian ini dilakukan dari bulan November 2020 sampai dengan bulan Juli 2021 yang dimulai dengan menyusun proposal sampai laporan hasil penelitian. Tahapan penelitian tindakan kelas mengacu pada Kemmis dan Taggart (dalam Parnawi, 2020) menggunakan 2 siklus dan masingmasing siklus terdiri dari empat tahapan yaitu rencana, pelaksanaan tindakan, observasi dan refleksi.

Teknik pengumpulan data yang digunakan yaitu berupa tes dan nontes. Dalam penelitian ini peneliti mengukur indikator kemampuan berpikir kreatif menggunakan non tes berupa wawancara dengan guru kelas, observasi saat proses pembelajaran dan kuesioner yang diberikan kepada siswa. Sedangkan tes yang digunakan berupa tes pilihan ganda untuk mengetahui hasil belajar siswa. Teknik tes digunakan dengan tujuan untuk memperoleh data hasil belajar siswa melalui pemberian soal evaluasi. Pemberian soal evaluasi peneliti lakukan sebanyak empat kali yaitu di setiap akhir pertemuan pada setiap siklus, dua pertemuan pada siklus I dan dua pertemuan pada siklus II. 
Teknik analisis data yang digunakan oleh peneliti dalam penelitian terdiri dua macam yaitu analisis kuantitatif dan analisis kualitatif deskriptif. Analisis kuantitatif digunakan untuk menguraikan capaian belajar siswa ditinjau dari hasil evaluasi. Sedangkan analisis kualitatif deskriptif digunakan untuk menguraikan tingkat berpikir kreatif siswa ditinjau dari hasil penyebaran kuesioner.

\section{HASIL DAN PEMBAHASAN}

Penelitian ini dilaksanakan dalam kegiatan pra siklus, siklus I, dan siklus II. Pada kegiatan prasiklus, peneliti melakukan observasi dan wawancara untuk mengetahui kondisi awal kelas yang sedang di teliti. Kemudian pada kegiatan 2 siklus, setiap siklus dilakukan 2 kali pertemuan dengan memanfaatkan model pembelajaran berbasis masalah, di mana setiap siklus terdiri dari 4 tahap yaitu tahap perencanaan, tahap pelaksanaan tindakan, observasi dan refleksi.

\section{Kemampuan Berpikir Kreatif}

Data berpikir kreatif siswa diperoleh dari lembar kuesioner yang diisi oleh siswa. Penyebaran kuesioner dilakukan ketika pra siklus dan diakhir setiap siklus. Peningkatan kemampuan berpikir kreatif siswa diukur berdasarkan data yang diperoleh dari hasil pengisian kuesioner pada kondisi awal sebelum tindakan, akhir siklus I, dan akhir siklus II. Berikut perbandingan data tersaji pada tabel 2:

Tabel 2. Perbandingan Rata-rata Nilai Kemampuan Berpikir Kreatif

\begin{tabular}{lcc}
\hline \multicolumn{1}{c}{ Tahapan } & Rata-rata Nilai & Keterangan \\
\hline Pra Siklus & 36.83 & Cukup Kreatif \\
Siklus I & 43.04 & Cukup Kreatif \\
Siklus II & 45.07 & Kreatif \\
\hline
\end{tabular}

Berdasarkan tabel 2 di atas berpikir kreatif siswa mengalami peningkatan pada tiap tahapnya. Kondisi awal sebelum melaksanakan penelitian, rata-rata berpikir kreatif siswa adalah 36.83 dengan kategori cukup kreatif. Sebanyak 15 siswa (32.6\%) dengan kategori kurang kreatif, 27 siswa $(58.7 \%)$ dengan kategori cukup kreatif, dan 4 siswa (8.7\%) dengan kategori kreatif.

Diakhir pelaksanaan siklus I dengan menerapkan model pembelajaran berbasis masalah menunjukkan adanya peningkatan berpikir kreatif siswa. Rata-rata berpikir kreatif siswa pada siklus I adalah 43,04 dengan kategori cukup kreatif. Dengan rincian terdapat sebanyak 25 siswa (54.3\%) dengan kategori kreatif, 10 siswa (21.7\%) dengan kategori cukup kreatif, dan 11 siswa (24\%) dengan kategori kurang kreatif.
Pada akhir siklus II dengan menerapkan model pembelajaran berbasis masalah menunjukkan adanya peningkatan berpikir kreatif siswa. Rata-rata berpikir kreatif siswa pada siklus II adalah 45.07 dengan kategori kreatif. Sebanyak 1 siswa $(2.2 \%)$ dengan kategori sangat kreatif, 33 siswa $(71.7 \%)$ dengan kategori kreatif, 7 siswa (15.2\%) dengan kategori cukup kreatif, dan 5 siswa (10.9\%) dengan kategori kurang kreatif.

\section{Hasil Belajar}

Data Hasil belajar diperoleh dari hasil kondisi awal (pra siklus), hasil nilai pada siklus I dan hasil nilai pada siklus II. Perbandingan hasil belajar siswa dari pra siklus, siklus I, dan siklus II tersaji pada tabel 3

Tabel 3. Perbandingan Hasil Belajar

\begin{tabular}{lcrc}
\hline \multicolumn{1}{c}{ Tahapan } & \multirow{2}{*}{ Rata-rata Nilai } & \multicolumn{2}{c}{ Persentase } \\
& & Tuntas & Tidak Tuntas \\
\hline Pra Siklus & 68.09 & $45.7 \%$ & $54.3 \%$ \\
Siklus I & 70.33 & $54.3 \%$ & $45.7 \%$ \\
Siklus II & 78.59 & $69.6 \%$ & $30.4 \%$ \\
\hline
\end{tabular}


Berdasarkan data pada tabel 3 di atas terlihat bahwa hasil belajar siswa mengalami peningkatan pada setiap siklus. Data nilai kondisi awal sebelum penelitian yaitu 68.09. Dari total siswa yang berjumlah 46 siswa, terdapat 21 siswa (45.7\%) yang tuntas dan 25 siswa (54.3\%) yang tidak tuntas.

Diakhir pelaksanaan siklus I dengan menerapkan model pembelajaran berbasis masalah menunjukkan adanya peningkatan hasil belajar siswa. Nilai rata-rata siswa pada siklus I adalah 70.33 dengan rincian terdapat sebanyak 25 siswa (54.3\%) yang tuntas sedangkan siswa yang tidak tuntas KKM sebanyak 21 siswa (54.3\%).
Pada akhir pelaksanaan siklus II dengan menerapkan model pembelajaran berbasis masalah menunjukkan adanya peningkatan hasil belajar siswa. Nilai rata-rata siswa pada siklus II adalah 78.59 dengan rincian terdapat sebanyak 32 siswa $(69.6 \%)$ yang tuntas sedangkan siswa yang tidak tuntas KKM sebanyak 14 siswa (30.4\%).

\section{Peningkatan Kemampuan Berpikir Kreatif dan Hasil Belajar Siswa}

Nilai rata-rata prasiklus, siklus $\mathrm{I}$, dan siklus II berdasarkan analisis hasil kuesioner dan hasil soal evaluasi dapat dilihat melalui tabel 4:

Tabel 4. Nilai Rata-rata Hasil Kuesioner Berpikir Kreatif dan Hasil Belajar

\begin{tabular}{|c|c|c|c|c|c|}
\hline \multirow{2}{*}{ No. } & \multirow{2}{*}{ Variabel } & \multirow{2}{*}{ Indikator } & \multicolumn{3}{|c|}{ Nilai Rata-rata } \\
\hline & & & Prasiklus & Siklus I & Siklus II \\
\hline 1. & Berpikir Kreatif & $\begin{array}{l}\text { Rata-rata kuesioner } \\
\text { berpikir kreatif }\end{array}$ & $\begin{array}{l}36.83 \\
\text { (Cukup } \\
\text { Kreatif) }\end{array}$ & $\begin{array}{l}43.04 \\
\text { (Cukup } \\
\text { Kreatif) }\end{array}$ & $\begin{array}{l}45.07 \\
\text { (Kreatif) }\end{array}$ \\
\hline 2. & Hasil Belajar & $\begin{array}{l}\text { Rata-rata hasil soal } \\
\text { evaluasi }\end{array}$ & 68.09 & 70.33 & 78.59 \\
\hline
\end{tabular}

Berdasarkan tabel 4 di atas, terbukti bahwa kedua variabel yang menjadi objek penelitian mengalami peningkatan pada setiap siklus. Berpikir kreatif dengan menggunakan empat indikator yang digunakan, menunjukkan adanya peningkatan di setiap indikator. Data kondisi awal pada kemampuan berpikir kreatif adalah 36.83 pada siklus I dengan target 40 kemampuan berpikir kreatif mengalami peningkatan menjadi 43.04 dan pada siklus II dengan target 45 , kemampuan berpikir kreatif siswa kembali mengalami peningkatan menjadi 45.07. Sementara itu, hasil belajar siswa juga mengalami peningkatan. Data kondisi awal rata-rata hasil belajar siswa adalah 68.09. Pada siklus I dengan target 70 , hasil belajar siswa mengalami peningkatan menjadi 70.33 dan pada siklus II dengan target 75 , hasil belajar siswa kembali mengalami peningkatan menjadi 78.59.

Berdasarkan proses perencanaan dan proses pelaksanaan pembelajaran yang diperoleh pada siklus I dan siklus II, maka pelaksanaan pembelajaran telah terlaksana dengan sangat baik dan peneliti telah berhasil dalam meningkatkan berpikir kreatif dan hasil belajar siswa dalam pembelajaran IPS menggunakan model pembelajaran berbasis masalah di kelas $\mathrm{V}$.

\section{SIMPULAN DAN REKOMENDASI}

Penggunaan model pembelajaran berbasis masalah dalam pembelajaran IPS dikelas V SD Kanisius Kalasan Kabupaten Sleman dapat meningkatkan kemampuanberpikir kreatif. Hal ini dibuktikan dengan hasil penelitian dan analisis data pada variabel berpikir kreatif menunjukkan peningkatan dengan hasil rata-rata berpikir kreatif yaitu pada data pra siklus 36.83 dengan kategori cukup kreatif, siklus I yaitu dengan rata-rata 43.04 dengan kategori cukup kreatif, dan siklus II dengan rata-rata 45.07 dengan kategori kreatif.

Berdasarkan hasil belajar siswa dalam pembelajaran IPS dengan menggunakan model pembelajaran berbasis masalah juga mengalami peningkatan. Hal ini dibuktikan dengan rekapitulasi hasil evaluasi pembelajaran yang dilaksakanan disetiap akhir siklus. Pada variabel hasil belajar menunjukkan peningkatan dengan 
hasil pada data awal hasil belajar yaitu 68.09, siklus I 70.33, dan siklus II 78.59.

Dari hasil penelitian tindakan kelas ini, dapat diajukan saran dan masukan yang dapat bermanfaat dalam kegiatan pembelajaran, diantaranaya guru dapat menggunakan model pembelajaran berbasis masalah dalam mata pelajaran IPS dan membuat siswa lebih aktif dalam proses kegiatan pembelajaran, guru dapat menggunakan model ini untuk meningkatkan kemampuan berpikir kreatif siswa dalam menyelesaikan permasalahan dalam kehidupan sehari-hari.

\section{DAFTAR PUSTAKA}

Darmadi. (2017). Pengembangan Model dan Metode Pembelajaran dalam Dinamika Belajar Siswa. Yogyakarta: Deepublish.

Harisudin, M. I. (2019). Secuil Esensi Berpikir Kreatif \& Motivasi Belajar Siswa. Bandung: PT Panca Terra Firma.

Lestari, E.T. (2020). Pendekatan Saintifik di Sekolah Dasar. Yogyakarta: Deepublish.

Marliani. (2015). Psikologi Perkembangan. Bandung: Pustaka Setia.

Nahdi, D. S. (2019). Keterampilan Matematika Di Abad 21. Jurnal Cakrawala Pendas, 5(2).

Nurani, Y., Hartati, S., \& Sihadi. (2020). Memacu Kreativitas Melalui Bermain. Jakarta Timur: PT Bumi Aksara.

Oktavia, S. A. (2020). Model-Model Pembelajaran. Yogyakarta : Deepublish.

Parnawi, Afi (2020). Penelitian Tindakan Kelas (Classroom Action Research). Yogyakarta: Deepublish.

Prayitno. (2009). Dasar Teori dan Praksis Pendidikan. Jakarta Pusat: Grasindo.

Sapriya. (2009). Pendidikan IPS Konsep dan Pembelajaran. Bandung: PT Remaja Rosdakarya.

Silalahi, T. M., Girsang, M. L., \& Ginting, M.B. (2020). Peran Emosi dalam Membangun Keterampilan Berpikir Kreatif Anak Usia Dini. Klaten: Lakeisha.

Sinar. (2018). Metode Active LearningI. Yogyakarta: Deepublish.

Titik, L. E. (2020). Pendekatan Saintifik di Sekolah Dasar. Yogyakarta: Deepublish. 